\title{
Islamic Philanthropy Development in Digital Era: New Strategy of Fund Raising and Supervision Program
}

\author{
Mansur Efendi ${ }^{1}$, Ferdi Arifin ${ }^{2}$ \\ IAIN Surakarta ${ }^{1}$, IAIN Surakarta ${ }^{2}$ \\ mansur.iainsolo@gmail.com
}

\begin{abstract}
Industry 4.0, which is a shape of fourth stage of industrial revolution, influences human life such as new media development. Nowadays, most people are being active users in digital world as a new social sphere. Many activities in social media affects various creative ideas, one of them is a medium of fund raising. As fourth stage of industrial revolution it does not cut off humanitarian acts for caring each other's, even its appearance can be alternative media to create various humanitarian acts. Islamic philanthropy has taken for granted New Media as developing model of fund raising and supervision program to enhance humanitarian acts. This study attempts to analyze developing of Islamic philanthropy phenomena in new media by utilizing qualitative method. The results is going to find a model of fund raising throughout new media and to create a program of supervision for sustainability acts as an effort to establish prosperous society. By this research, Islamic philanthropy is able to develop rapidly and achieve wider success through a new strategy. The main aspect of new strategy model must be synchronized to Islamic laws embedded in Quran and Hadits for avoiding inappropriate ways and debatable rules.
\end{abstract}

Keywords: Islamic philanthropy, new media, fund raising and supervision program, industry 4.0

\begin{abstract}
Abstrak
Hadirnya industri 4.0 sebagai bentuk revolusi industri babak keempat ternyata mempengaruhi berbagai aspek kehidupan, salah satunya adalah perkembangan dalam Media Baru. Kebanyakan masyarakat saat ini aktif dalam dunia digital sebagai ruang sosial baru bagi mereka. Berbagai aktifitas dalam media sosial memunculkan berbagai ide kreatif seperti untuk media penggalangan dana bantuan. Babak keempat media revolusi industri ini ternyata tidak melepaskan sifat humanisme manusia untuk saling peduli dengan sesama, bahkan hadirnya media sosial bisa menjadi alternatif untuk melakukan berbagai tindakan kemanusiaan. Dunia filantrofi Islam harus bisa memanfaatkan Media Baru sebagai pengembangan model fund raising dan program supervisi untuk meningkatkan aktifitas kemanusiaan. Penelitian ini menganalisis fenomena perkembangan filantropi Islam dalam media baru dengan pendekatan kualitatif. Hasil dari penelitian ini merekomendasikan strategi baru untuk model fund raising melalui media baru dan program supervisi untuk keberlanjutan menciptakan masyarakat yang madani. Melalui rumusan hasil temuan penelitian ini, filantrofi Islam dapat berkembang dengan cepat dan mengupayakan jangkauan yang lebih luas melalui strategi baru dalam media baru. Aspek terpenting dari model strategi baru ini harus disinkronisasikan dengan aturan-aturan yang ada dalam hukum Islam untuk menghindari hal-hal yang tidak sesuai.
\end{abstract}

Kata Kunci: filantropi Islam, media baru, penggalangan dana dan program supervisi, industri 4.0. 


\section{PENDAHULUAN}

Pertumbuhan ekonomi Indonesia saat ini dinilai sangat bagus. Saat ini pertumbuhan ekonomi Indonesia di tahun 2017 akhir mencapai 5,1\%. Hal ini dianggap sebagai pertumbuhan ekonomi terbaik sejak tahun 2014 yang mencapai 5,01\%, tahun 2015 sebesar 4,88\%, dan di tahun 2016 sebesar 5,03\%. Meskipun target pertumbuhan ekonomi Indonesia di angka 5,2\%, setidaknya kinerja pemerintah saat ini dinilai cukup (Anonymous, 2017b; Pambudhy, 2018; Setiawan, 2018). Hal ini tidak lepas dari keuntungan Indonesia yang mengalami bonus demografi yang menggunakan usia muda sebagai motor penggerak pembangunan ekonomi. Selain itu, dampak krisis ekonomi global yang terjadi tidak mempengaruhi Indonesia dikarenakan angko konsumerisme di Indonesia masih terbilang tinggi (Anonymous, 2018b).

Pertumbuhan ekonomi yang dinilai baik ini ternyata serta merta menyelesaikan permasalahan ekonomi Indonesia. Faktanya, rasio gini Indonesia justru semakin luas dan naik. Terhitung sejak tahun 1990-an sampai 2000-an, rasio gini di Indonesia di kisaran +0.09 dan menempati posisi kedua negara-negara Asia lainnya (Anonymous, 2017a).

Table 1. Rata-rata rasio gini tertinggi di negara-negara Asia

\begin{tabular}{lccc}
\hline Negara & $\begin{array}{c}\text { Rasio Gini } \\
\text { 1990-an }\end{array}$ & $\begin{array}{c}\text { Rasio Gini } \\
\text { 2000-an }\end{array}$ & Kesejangan \\
\hline China & 0.34 & 0.45 & +0.11 \\
\hline Indonesia & 0.30 & 0.39 & +0.09 \\
\hline Laos & 0.32 & 0.38 & +0.06 \\
\hline India & 0.34 & 0.39 & +0.05 \\
\hline Vietnam & 0.37 & 0.37 & 0.00 \\
\hline Kamboja & 0.39 & 0.38 & -0.01 \\
\hline Filipina & 0.45 & 0.44 & -0.01 \\
\hline Malaysia & 0.49 & 0.47 & -0.02 \\
\hline Thailand & 0.46 & 0.41 & -0.05
\end{tabular}

Fakta tersebut sangat mencengangkan ketika pertumbuhan ekonomi Indonesia meningkat tetapi rasio gini di Indonesia juga meluas. Kesenjangan ekonomi seperti ini terjadi di belahan daerah di Indonesia. Sebaran penduduk miskin terbesar berada di Jawa dengan 15,36 juta penduduk, diikuti Sumatra dengan 6,1 juta jiwa, Sulawesi (termasuk Bali dan Nusa Tenggara) dengan 1,98 juta jiwa, Maluku dan Papua dengan 1,64 juta jiwa, dan yang menduduki posisi terendah penduduk miskin berada di Kalimantan dengan kisaran kurang dari 1 juta jiwa (Wahid, 2014). Sebaran kemiskinan tersebut ternyata lebih banyak terjadi di desa daripada di kota. Namun, BPS (Badan Pusat Statistik) meyakini meskipun masih banyak sebaran penduduk miskin dan rasio gini yang meluas, angka tersebut sudah mulai menurun sebesar 0,002 poin terhitung pada September 2017 (Anonymous, 2018a).

Meskipun pemerintah Indonesia melalui data BPS meyakini bahwa dapat menyelesaikan masalah ini, tetapi fakta yang bisa kita lihat melalui data BPS 

and Supervision Program

tentang kemiskinan yang terjadi di Indonesia selalu pasang surut. Dengan kata lain, kemiskinan bukan hanya permasalahan yang harus diselesaikan oleh pemerintah saja, melainkan oleh semua elemen masyarakat. Dalam perspektif Islam, masalah kemiskinan juga menjadi perhatian khusus melalui tuntunan untuk zakat, infaq, dan sodaqoh. Sejauh ini ZIS (zakat, infaq, sodaqoh) hanya diperhatikan oleh Kementrian Agama, ormas Islam, dan beberapa lembaga filantropi Islam. Sejauh ini, setidaknya ada sekitar 20 ZIS yang sudah diakui oleh pemerintah melalui Peraturan Pemerintah Nomor 60 Tahun 2010 tentang Zakat dan Sumbangan Keagamaan yang Sifatnya Wajib Dapat Dikurangkan dari Penghasilan Bruto (Nia, 2011).

\section{KAJIAN LITERATUR}

Berdasarkan beberapa kajian yang ada, di Indonesia sendiri memiliki potensi zakat mencapai Rp. 442 triliun jika dilihat dari 3,4\% dari PDB nasional, jika dilihat dari 1,7\% PDB nasional memiliki potensi zakat mencapai Rp. 221 triliun, sedangkan jika dilihat dari 0,8\% PDB nasional potensi zakat mencapai Rp. 104 triliun. Dari semua potensi yang dilakukan tersebut, estimasi pengumpulan zakat hanya mencapai sekitar Rp. 4,4 triliun saja (Wibisono, 2016). Dengan kata lain, ada gap yang muncul jika melihat potensi zakat lebih besar daripada pengumpulan zakat. Ada hal yang harus dipecahkan untuk dapat menekan gap antara potensi dan pengumpulannya. Oleh karena itu, penelitian ini akan menunjukkan bagaimana memaksimalkan zakat di era industry 4.0 sebagai upaya penekanan gap antara potensi dan pengumpulan zakat.

\section{METODE PENELITIAN}

Melalui model penelitian kualitatif, tulisan ini akan melihat berbagai laporan lembaga atau organisasi yang berkaitan dengan ZIS dan mengamati programprogram kerja mereka dalam upaya pengumpulan ZIS. Dengan komparasi berbagai lembaga atau organisasi khusus ZIS, tulisan ini dapat melihat bagian mana yang menjadi gap antara potensi dan pengumpulan zakat selama ini. Terlebih lagi, fenomena industry 4.0 dan generasi millennial saat ini mendapatkan perhatian khusus dari pelbagai kajian sosial humaniora. Dengan model komparasi program antarlembaga ZIS dan karakteristik fenomena yang ada saat ini, tulisan ini akan memberikan penawaran yang dapat menekan gap dalam potensi zakat dan pemerolah dana zakat dari masyarakat.

\section{PEMBAHASAN}

\section{Optimalisasi Organisasi Filantropi Islam}

Pada bagian ini kita akan melihat bagaimana organisasi atau lembaga ZIS dalam proses pengumpulan dan distribusi ZIS di Indonesia. Tahun 2016, laporan BAZNAS menunjukkan bahwa pengumpulan ZIS dari BAZNAS dan LAZ (Lembaga Amil Zakat) di Indonesia mencapai Rp. 3.653.273.250.292,- dengan rincian di bawah. 
Table 2. Jumlah penghimpunan dana berdasarkan jenis dana

\begin{tabular}{llrl}
\hline No & \multicolumn{1}{c}{ Jenis Dana } & \multicolumn{1}{c}{ Realisasi 2015 } & Presentase \\
\hline 1 & $\begin{array}{l}\text { Zakat (termasuk zakat } \\
\text { fitrah) }\end{array}$ & $2,312,195,596,498$ & 63.29 \\
\hline 2 & Infaq/sedekah & $1,176,558,166,696$ & 32.31 \\
\hline 3 & $\begin{array}{l}\text { Dana sosial keagamaan } \\
\text { lainnya }\end{array}$ & $163,986,086,154$ & 4.49 \\
\hline 4 & Dana lain-lainnya & $533,400,945$ & 0.01 \\
\hline & Jumlah & $3,653,273,250,292$ & 100
\end{tabular}

(BAZNAS, 2016)

BAZNAS (Badan Amil Zakat Nasional) adalah lembaga pemerintah yang nonstruktural hanya mampu memperoleh Rp. 3,6 triliun, sedangkan potensi zakat pada tahun 2016 bisa mencapai di atas 100 triliun rupiah. Dalam hal ini kita bisa melihat ada gap yang jauh antara target dan capaian. Padahal program dan layanan yang diberikan BAZNAS sangat banyak dan sangat mudah diakses oleh siapa dan kapan saja. Ada beberapa layanan yang diberikan seperti zakat via payroll system, bizzakat, e-card, online payment, perbankan syariah, dan konter. Ada juga jasa layanan konsultasi online, konfirmasi pembayaran, registrasi online, jemput zakat, muzaki corner, dan unit pengumpul zakat BAZNAS. Selain itu, BAZNAS juga memiliki program khusus untuk memaksimalkan usahanya dalam upaya pengumpulan dan penyaluran dana zakat melalui Zakat Community Development, Rumah Sehat BAZNAS, Rumah Cerdas Anak Bangsa, Konter Layanan Mustahik, dan BAZNAS Tanggap Bencana.

Tidak hanya BAZNAS, bahkan LAZ juga menyediakan layanan khusus untuk memudahkan para muzakki dan mengadakan program-program yang menyukseskan program ZIS sesuai ketentuan dan ajaran Islam. Namun, tetap saja berbagai kemudahan untuk mengakses informasi seputas ZIS dan menyalurkan sebagian hartanya untuk ZIS tetap masih dirasa kurang. Perlu ada skema khusus dalam rangka menekan gap potensi ZIS dengan hasil perolehan pengumpulan dana ZIS.

Sebagaimana kita tahu bahwa zakat menjadi sebuah tuntunan bagi umat Islam, beberapa perspektif mengenai ZIS ini sebenarnya juga harus dipahami secara seksama. Dalam sebuah kajian mengenai zakat memaparkan konsep mengenai kegiatan ini bagi orang Indonesia dianggap sebagai upaya membersihkan jiwa dan raga, orang Mesir beranggapan zakat sebagai upaya membersihkan jiwa dan harta karena sebagaian dari harta yang dimiliki adalah hak orang-orang miskin, sedangkan bagi orang Jordan dan Palestina menganggap zakat sebagai communal trust atau suatu upaya untuk mencapai kesejahteraan (Benthall, 1999; Carkoglu, 2004; Center for Languages and Cultures, 2004; Hassan, 2007).

Padahal, apabila ZIS bisa dimaksimalkan pastinya tidak menutup kemungkinan untuk membantu pemerintah dalam uapaya menekan rasio gini dan kemiskinan di Indonesia. Sebagaimana upaya OJK (Otoritas Jasa 

and Supervision Program

Keuangan) yang mencoba menggagas ekonomi inklusif melalui program KUR (Kredit Usaha Rakyat) di daerah-daerah untuk menekan angka kemiskinan desa dan kota (Wahid, 2014), filantopi Islam melalui penggalangan dana ZIS dapat membantu upaya ini. Hal ini bisa mengambil bagian dalam membangun keadilan sosial (Fauzia, 2017). Di Indonesia, keadilan sosial masuk dalam Pancasila sehingga optimalisasi ZIS ini juga sebagai upaya perwujudan sila kelima. Oleh karena itu, sebuah hasil penelitian memaparkan setidaknya lebih dari 65\% penduduk Muslim sepakat terhadap keadilan sosial sebagai bentuk perwujudan Pancasila sekaligus sebagai upaya tolong-menolong antarsesama dalam adil secara hak, pendapatan, hak kesetaraan terhadap perempuan dan kaum minoritas, serta dalam kesetaraan berekspresi (Abubakar \& C, 2006).

Untuk mewujudkan itu semua, organisasi filantropi Islam yang digawangi oleh BAZNAS harus mengoptimalisasikan upayanya dalam pengumpulan dana ZIS dan distribusi hasil pengumpulan dana ZIS tersebut. Namun, apabila dilihat dari program dan layanan yang diberikan oleh berbagai OPZ (Organisasi Pengumpul Zakat) sudah sangat baik meskipun pendapatan dana ZIS masih jauh dari potensi ZIS yang ada di Indonesia. Indonesia juga dinobatkan sebagai negara yang memiliki orang-orang kaya dermawan nomor dua di dunia oleh Forbes (Barlian, 2016). Dengan kata lain, optimalisasi pengumpulan dana ZIS bisa dimaksimalkan melalui sikap dan karakter orang-orang Indonesia yang dermawan.

Optimalisasi pengumpulan dana ZIS bukan tidak memiliki alasan. Beberapa hal yang menjadi alasan khusus dalam optimalisasi ini muncul keberagaman, yaitu dari sudut pandang BAZNAS menganggap jauhnya gap potensi ZIS dengan pendapatan ZIS terdapat pada sinkronisasi dan koordinasi antarorganisasi dengan menciptakan regulasi yang ideal, sedangkan dari sudut pandang LAZ di luar organisasi luar pemerintah menganggap aturan dalam proses pendirian LAZ sangat membatasi dan audit keuangan yang dinilai kurang sesuai (Anonymous, n.d.; Nadlir, 2017; Nasar, 2015).

Apabila ditarik ke dalam analisis SWOT (Strength, Weakness, Opportunity, Threatening) terdapat beberapa temuan yang bisa dipetakan. Prioritas kekuatan sebuah OPZ ini berada pada hukum, baik hukum agama Islam maupun hukum pemerintahan yang ditetapkan dalam Undang-Undang; prioritas kelemahan sebuah OPZ muncul karena lemahnya database dari Mustahik dan audit keuangan yang masih dirasa kurang transparan; prioritas peluang OPZ ada pada demografi Indonesia yang mayoritas beragama Islam; dan prioritas ancaman OPZ muncul karena kurangnya wawasan masyarakat terhadap zakat dan kepercayaan mereka terhadap OPZ (Ali, 2014).

Jika kita melihat analisis SWOT terhadap OPZ dan beberapa pandangan mengenai lemahnya sinkronisasi dan koordinasi organisasi OPZ di Indonesia saat ini, seharusnya itu bisa dicarikan solusi. Mengingat sekarang adalah era industry 4.0 yang memanfaatkan dunia digital sebagai platform atau sebagai pengganti ruang realitas menjadi virtual, permasalahan mengenai kelemahan, ancaman, sinkronisasi, dan koordinasi bisa dipecahkan. Hal ini dikarenakan era industri 4.0 sudah digunakan untuk menangkan market share sebuah 
perusahaan dan monitoring proses dalam suatu industri (Almada-Lobo, 2016) sehingga bisa juga dimanfaatkan untuk melihat potensi siapa saja yang menjadi Mustahik dan Muzakki dengan mudah.

Optimalisasi Filantropi Islam dalam Menekan Rasio Gini dan Kemiskinan Kemiskinan adalah masalah di semua negara. Semua negara memiliki faktor penyebab kemiskinan masing-masing, seperti negara berkembang menganggap kemiskinan dikarenakan eksploitasi sedangkan negara maju melihat kemiskinan muncul karena faktor alam dan lain sebagainya (Harper \& Manasse, 1992; Hine \& Montiel, 1999). Di Indonesia sendiri, jumlah penduduk miskin tercatat sebanyak 26,58 juta orang atau $10,12 \%$ dari total populasi (Badan Pusat Statistik, 2018b). Di sisi lain, rasio gini yang terjadi di Indonesia mencapai 0,391 poin terhitung sejak September 2017 (Anonymous, 2018a).

Melihat hal ini filantropi Islam bisa menjadi salah satu motor untuk menekan angka kemiskinan dan mempersempit rasio gini yang terjadi di Indonesia. Sebagaimana program filantropi Islam di Demak melalui pengelolaan dan pemberdayaan ZIS (Zakat, Infaq, Sodaqoh, Wakaf) yang dilakukan oleh BMT (Baitul Maal wa Tamwil) se-Kabupaten Demak, filantropi Islam di Jember melalui program pemberdayaan dan bantuan kebutuhan langsung, alokasi dana ZIS melalui potongan gaji seperti yang dilakukan oleh filantropi Islam di Yogyakarta, pengelolaan dana untuk peningkatan mutu pendidikan kaum dhuafa, dan sebagainya (Kasdi, 2016; Kholis, Sobaya, Andriansyah, \& Iqbal, 2013; Nasrullah, 2015; Rahmayati, 2015).

Namun, berdasarkan beberapa kajian filantropi Islam di daerah tersebut belum bisa dikatakan mendapatkan kesuksesan. Hal ini dikarenakan apa yang kita bahas sebelumnya jika ada beberapa prolematika dalam filantropi Islam secara nasional, seperti sinkronisasi, koordinasi, pendataan, dan aspek kepercayaan masyarakat kepada OPZ di berbagai daerah. Tidak menutup kemungkinan bahwa banyak aspek yang harus diperhatikan karena setiap daerah di Indonesia memiliki karakteristik yang berbeda-beda. Optimalisasi filantropi Islam untuk bisa menangkap potensi ZIS di Indonesia dan mengimplementasikannya seperti kesuksesan filantropi Islam di beberapa daerah bisa dikolaborasikan dengan berbagai fenomena yang muncul saat ini, yaitu pemanfaatan internet sebagai prioritas mencari solusi terbaik dalam menghadapi masalah filantropi Islam di Indonesia.

\section{Optimalisasi fundraising melalui pemasaran}

Sejauh ini BAZNAS dan LAZ sudah berupaya memberikan berbagai layanan dan program untuk memudahkan mengumpulkan ZIS. Namun, tetap saja dalam OPZ belum bisa maksimal dalam menangkap potensi ZIS di Indonesia (Badan Amil Zakat Nasional, 2017). Untuk menindaklanjuti persoalan potensi dan capaian pengumpulan ZIS ini perlu adanya pemetaan secara spesifi. Terlebih lagi di era industri 4.0 yang sangat bergantung pada internet ini, kita harus bisa melihat perilaku pasar (calon muzakki) untuk menumbuhkan minat dan kerelaan dalam ZIS. 

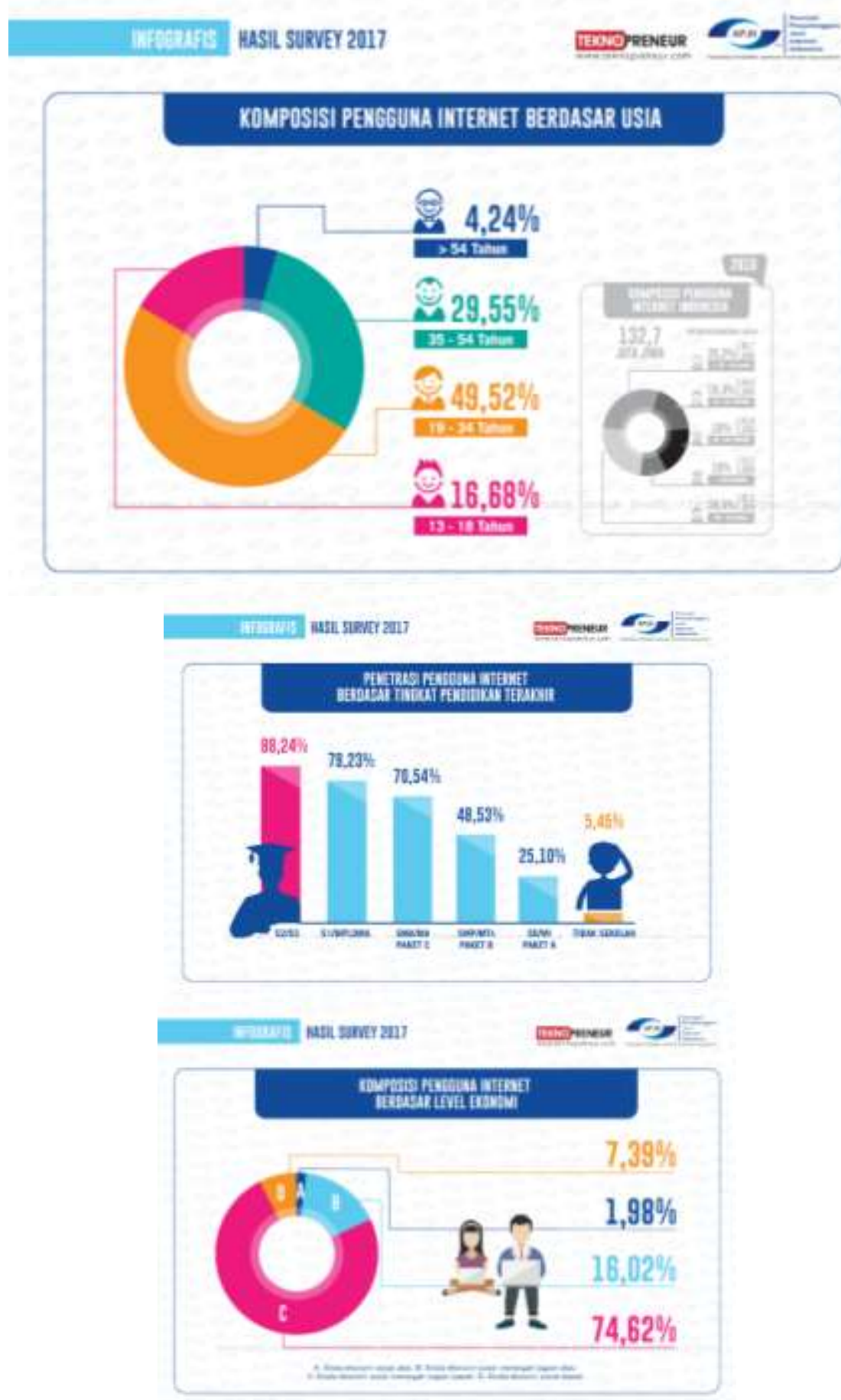

(APJII, 2017)

Grafik yang ditampilkan di atas bisa menjadi langkah awal untuk optimalisasi pengumpulan ZIS di Indonesia. Meskipun OPZ sudah memberikan layanan dan program yang mudah diakses oleh para muzakki, tetapi jika program itu tidak disosialisasikan dengan seksama sama halnya program dan layanan yang diberikan menjadi angina lalu saja. 
Perlu kita ketahui bahwa upaya fundraising ini sama halnya dengan uapaya untuk meyakinkan orang untuk membeli produk sebuah perusahaan. Oleh karena itu, pemasaran adalah suatu hal yang penting untuk dilakukan oleh OPZ dalam optimalisasi potensi ZIS. Terkadang organisasi sosial melupakan bahwa pemasaran itu hanya untuk mencari profit, padahal pemasaran lebih dari sekedar mencari profit, yaitu pemasaran untuk memunculkan persepsi (Cluley, 2016). Dengan kata lain, OPZ seharusnya tidak hanya menyediakan layanan dan program untuk mempermudah akses para muzakki, tetapi juga membuat sebuah narasi tertentu untuk mempengaruhi persepsi seseorang dalam ZIS.

Dalam upaya mencari narasi apa yang sekiranya sesuai untuk mempengaruhi psikologis, perlu adanya penelaahan model motivasi masyarakat Indonesia. Dalam sebuah kajian ilmu pemasaran, ada lima motivasi dasar yang sangat penting atau disebut Key Underlying Motivating Values atau KUMe values (Wolfe, 1997).

1. Indentity values: keberlangsungan hidup dan integritas masing-masing individu

2. Relational values: hubungan individu dengan kehidupan

3. Centering values: tujuan perseorangan

4. Adaptional values: nilai-nilai diri yang dikembangkan

5. Conservation and renewal values: manajemen energi masing-masing individu

Kelima kunci tersebut dianggap sebagai akar dari motivasi individu yang dapat mempengaruhi psikologis seseorang untuk bertindak. Untuk bisa mencapai itu semua, OPZ perlu melihat database dari calon muzakki karena hal itu diperlukan untuk menerjemahkan maksud dan tujuan dari OPZ secara lengkap serta sebagai upaya untuk mengetahui keinginan dari calon muzakki dan memberikan kepuasan kepada para muzakki (McCarthy \& Perreault, 1987). Pemanfaatan database ini bukan hanya sekedar untuk menginformasikan dan mengajak orang untuk ZIS tetapi juga sebagai upaya sarana untuk menjaga loyalitas dan kepercayaan orang terhadap perusahaan (Schoenbachler et al., 1997) dalam kasus ini adalah OPZ.

Ketersediaan data pengguna internet di Indonesia yang meliputi klasifikasi umur, ekonomi, serta pendidikan yang disediakan oleh APJII akan lebih mempermudah OPZ untuk pemetaan dalam upaya optimalisasi fundraising di daring. Dengan kata lain, upaya ini bisa menjadi salah satu rekomendasi dari tulisan ini kepada OPZ untuk bisa memanfaatkan internet bukan semata-mata untuk memberikan kemudahan layanan melainkan juga sebagai upaya untuk memasarkan produk OPZ dalam meningkatkan pendapatan dana ZIS.

\section{ZIS untuk keadilan sosial melalui socio entrepreneurship}

Hasil dari optimalisasi fundraising ZIS melalui proses pemasaran yang tepat tidak menutup kemunkinan akan berdampak pada keadilan sosial bagi seluruh rakyat. Meskipun BPS menyatakan bahwa pertumbuhan ekonomi Indonesia dinyatakan tumbuh 5,19 persen (Badan Pusat Statistik, 2018a) dan 

and Supervision Program

angka kemiskinan Indonesia sebesar 10,12 persen atau jumlah penduduk miskin turun hingga 1,19 juta jiwa (Badan Pusat Statistik, 2018c), tetapi rasio gini di Indonesia justru meluas hingga 0.09 poin (Anonymous, 2017a). Dengan kata lain, perekonomian tumbuh tetapi kesenjangan meluas.

Hasil ini bisa kita rumuskan bahwa pertumbuhan ekonomi Indonesia semakin baik tetapi keadilan sosial belum merata yang ditunjukkan melalui peningkatan poin rasio gini Indonesia dalam kurun tahun tertentu. Seperti yang sudah didiskusikan sebelumnya, filantropi Islam melalui ZIS bisa menjadi salah satu upaya untuk pemerataan keadilan sosial dan ekonomi untuk masyarakat secara luas. Melalui optimalisasi potensi ZIS dengan pemasaran yang tepat, OPZ bisa mengelola ZIS tersebut melalui optimalisasi program socio entrepreneurship.

Socio entrepreneurship dianggap sebagai sebuah konsep bisnis yang diperuntukkan untuk sosial secara menyeluruh melalui upaya-upaya pemecahan masalah sosial (Haynes, 2011; Lawrence, Phillips, \& Tracey, 2012; Tracey \& Phillips, 2007). Dengan kata lain, socio entrepreneurship merupakan suatu model bisnis untuk memecahkan bebergai masalah sosial melalui pendapatan dari sebuah model usaha yang dijalankan. Untuk bisa melakukan hal ini, OPZ harus merumuskan manajemen pengelolaannya, baik untuk pengumpulan, pengelolaan, dan distribusinya. Ada tiga aspek penting yang diperlukan dalam menjalankan model ini, seperti framing yaitu konseptualisasi nilai-nilai kebersamaan yang dapat memobilisasi tindakan secara kolektif; convening yaitu meyakinkan individu, kelompok, atau jaringan untuk bersama-sama memecahkan problem sosial yang terjadi; multivocality yaitu mengkombinasikan berbagai masukan dan sudut pandang untuk dikomunikasikan (Pless, 2012).

Selaras dengan proses pemasaran, model framing adalah mencari nilai-nilai yang dianggap penting oleh masyarakat, model convening juga menjadi sarana untuk meyakinkan para muzakki atau calon muzakki jika tindakan ZIS adalah salah satu sarana untuk mereka bersikap adil bagi sosial dengan cara terlibat langsung atau tidak langsung dalam proses pemecahan masalah sosial yang ada, sedangkan model multivocality bisa digunakan sebagai sarana untuk mengkomunikasikan konseptualisasi dari banyaknya pemikiran dan sudut pandang supaya meyakinkan semua pihak bahwa kegiatan yang dilakukan ini bukan semata-mata mencari profit saja, melainkan sebagai upaya transparasi kegiatan yang akan dilakukan secara kolektif untuk kemaslahatan umat.

Dengan cara seperti ini, alokasi dana ZIS bisa dimanfaatkan secara produktif oleh para filantropi Islam melalui program socio entrepreneurship yang dijalankan dengan penuh kesepakatan dan kesadaran, bukan semata-mata karena ideology atau pandangan tertentu saja. Dengan demikian, apabila pengelolaan dana ZIS melalui model ini dapat dimaksimalkan, tidak menutup kemungkinan para filantropi Islam di Indonesia akan sangat membantu pemerintah Indonesia dalam upaya menekan angka kemiskinan dan mempersempit rasio gini yang saat ini terjadi di tengah laju pertumbuhan 
ekonomi Indonesia. Selain itu, kesuksesan filantropi Islam juga bisa menjadi aktor utama dalam proses mewujudkan keadilan sosial bagi seluruh rakyat.

\section{SIMPULAN}

Filantropi Islam melalui OPZ di Indonesia ini memang memiliki tantangan tersendiri. Perkembangan zaman di era industri 4.0 harus bisa disikapi dengan seksama karena fenomena masyarakat saat ini semakin kompleks. Penyediaan berbagai program dan layanan para OPZ memang sudah baik, tetapi akan lebih baik lagi jika bisa memetakan berbagai fenomena yang silih berganti. Upaya optimalisasi fundraising harus diperhatikan dengan seksama mengingat potensi ZIS di Indonesia yang sangat luar biasa tetapi pengumpulan dZIS yang masih jauh dengan potensinya. Dunia digital menjadi sarana yang bisa memiliki kebermanfaatan atau justru menciptakan kebingungan yang tersendiri. Filantropi Islam harus lebih seksama memetakan persoalan yang terjadi dalam proses optimalisasi pengumpulan dana ZIS melalui data-data yang sudah dimiliki dan optimalisasi distribusi dana ZIS supaya tepat sasaran dan tepat guna. Selain itu, filantropi Islam melalui socio entrepreneurship bisa menjadi suatu upaya untuk mewujudkan kesejahteraan dan keadilan sosial ekonomi bagi seluruh elemen masyarakat. Dengan demikian, tulisan ini merekomendasikan kepada para pelaku filantropi Islam harus duduk bersama merumuskan berbagai upaya optimalisasi pengumpulan dana ZIS dan pendistribuan dana ZIS secara tepat sasaran. 

and Supervision Program

\section{DAFTAR PUSTAKA}

Abubakar, I., \& C, B. (2006). Filantropi Islam dan Keadilan Sosial: Studi Tentang Potensi, Tradisi, dan Pemanfaatan Filantropi Islam di Indonesia. Jakarta: Pusat Studi Agama dan Budaya, Universitas Islam Negeri Syarif Hidayatullah.

Ali, K. M. (2014). Strategi Pengembangan Organisasi Pengelola Zakat. Retrieved April 22, 2018, from http://republika.co.id/berita/koran/iqtishodia/14/09/25/ncfxw824-strategipengembangan-organisasi-pengelola-zakat

Almada-Lobo, F. (2016). The Industry 4.0 revolution and the future of Manufacturing Execution Systems (MES). Journal of Innovation Management, $3(4), \quad 17 . \quad$ Retrieved from file:///C:/Users/Marco11/Downloads/249-1022-1-PB (1).pdf

Anonymous. (n.d.). Tigas Masalah Utama. Retrieved April 21, 2018, from https://forumzakat.org/blog/tiga-masalah-utama/

Anonymous. (2017a). Kemiskinan di Indonesia. Retrieved April 20, 2018, from https://www.indonesia-investments.com/id/keuangan/angka-ekonomimakro/kemiskinan/item301?

Anonymous. (2017b). Laporan Triwulanan Perekonomian Indonesia Maret 2017: Melanjutkan Perbaikan. Retrieved April 20, 2018, from http://www.worldbank.org/in/country/indonesia/publication/indonesiaeconomic-quarterly-march-2017

Anonymous. (2018a). Gini Ratio September 2017 tercatat sebesar 0,391. Retrieved April 20, 2018, from https://www.bps.go.id/pressrelease/2018/01/02/1410/gini-ratio-september2017-tercatat-sebesar-0-391.html

Anonymous. (2018b). Pertumbuhan Ekonomi Indonesia. Retrieved April 20, 2018, from https://www.indonesia-frankfurt.de/ekonomi/pertumbuhan-ekonomiindonesia/

APJII. (2017). Penetrasi \& Perilaku Pengguna Internet Indonesia 2017. Asosiasi Penyelenggara Jasa Internet Indonesia, 1-39.

Badan Amil Zakat Nasional. (2017). 2017 Outlook Zakat Indonesia. Jakarta.

Badan Pusat Statistik. (2018a). Ekonomi Indonesia Triwulan IV-2017 Tumbuh 5,19 Persen. Retrieved April 27, 2018, from https://www.bps.go.id/pressrelease/2018/02/05/1519/ekonomi-indonesiatriwulan-iv-2017--tumbuh-5-19-persen.html

Badan Pusat Statistik. (2018b). Persentase Penduduk Miskin September 2017 Mencapai 10,12 persen. Retrieved April 22, 2018, from https://www.bps.go.id/pressrelease/2018/01/02/1413/persentase-pendudukmiskin-september-2017-mencapai-10-12-persen.html

Badan Pusat Statistik. (2018c). Persentase Penduduk Miskin September 2017 Mencapai 10,12 persen. Retrieved April 27, 2018, from https://www.bps.go.id/pressrelease/2018/01/02/1413/persentase-pendudukmiskin-september-2017-mencapai-10-12-persen.html

Barlian, J. K. (2016). Forbes Nobatkan Orang Kaya Indonesia Paling Dermawan No.2 di Dunia. Retrieved April 21, 2018, from https://swa.co.id/swa/forbesnobatkan-orang-kaya-indonesia-paling-dermawan-no-2-di-dunia 
BAZNAS. (2016). Dokumen Statistik BAZNAS 2016. Jakarta: BAZNAS.

Benthall, J. (1999). Financial Worship; the Quranic injunction to almsgiving. Journal of the Royal Anthropological Institute, 5(1).

Carkoglu, A. (2004). Philanthropy in Turkey. Istanbul: Tusev.

Center for Languages and Cultures. (2004). Philanthropy for Social Justice in Muslim Societies: Indonesian Case studies. Jakarta.

Cluley, R. (2016). The depiction of marketing and marketers in the news media. European Journal of Marketing, 50(5/6), 752-769. https://doi.org/10.1108/EJM-02-2015-0076

Fauzia, A. (2017). Islamic Philanthropy in Indonesia: Modernization, Islamization, and Social Justice. Austrian Journal of South-East Asian Studies, 10(2), 223237. https://doi.org/10.14764/10.ASEAS-2017.2-6

Harper, D. J., \& Manasse, P. R. (1992). The just world and the Third World: British explanations of poverty abroad. Journal of Social Psychology, 132, 783 \pm 785 .

Hassan, R. (2007). Giving and Gaining: Philanthrophy and Social Justice in Muslim Societies. Lahore Journal of Policy Studies, 1(1). Retrieved from http://121.52.153.178:8080/xmlui/bitstream/handle/123456789/6259/GIVIN G AND GAINING PHILANTHROPY AND.pdf?sequence=1\&isAllowed=y

Haynes, P. (2011). Theorising the emerging field of social entrepreneurship. Journal of Social Entrepreneurship and Innovation, 1(2), 145-155.

Hine, D. W., \& Montiel, C. J. (1999). Poverty in developing nations: A cultural attributional analysis. European Journal of Social Psychology, 29(February), 943-959. https://doi.org/https://doi.org/10.1002/(SICI)10990992(199911)29:7<943::AID-EJSP978>3.0.CO;2-5

Kasdi, A. (2016). Filantropi Islam Untuk Pemberdayaan Ekonomi Umat (Model Pemberdayaan ZIS di BMT Se-Kabupaten Demak). Jurnal Iqtishadia, 9(2). https://doi.org/http://dx.doi.org/10.21043/iqtishadia.v9i2

Kholis, N., Sobaya, S., Andriansyah, Y., \& Iqbal, M. (2013). Potret Filantropi Islam di Propinsi Daerah Istimewa Yogyakarta. La Riba Jurnal Ekonomi Islam, 3(7), 61-84.

Lawrence, T., Phillips, N., \& Tracey, P. (2012). Introduction: interviews and essays on educating social entrepreneurs and social innovators. Academy of Management Learning \& Education, 11(3), 419-420.

McCarthy, E. ., \& Perreault, M. J. (1987). Basic Marketing.

Nadlir, M. (2017). Gelar Rakornas 2017, Baznas Ungkap Kendala dalam Pengumpulan Zakat. Retrieved April 21, 2018, from https://nasional.kompas.com/read/2017/10/04/21482321/gelar-rakornas-

2017-baznas-ungkap-kendala-dalam-pengumpulan-zakat

Nasar, M. F. (2015). Reorganisasi BAZNAS di Daerah dan Permasalahannya. Retrieved April 21, 2018, from http://pusat.baznas.go.id/poskoaceh/reorganisasi-baznas-di-daerah-dan-permasalahannya/

Nasrullah, A. (2015). Pengelolaan Dana Filantropi Untuk Pemberdayaan Pendidikan Anak Dhuafa (Studi Kasus Pada BMH Cabang Malang Jawa Timur). Jurnal Hunafa, 12(1), 1-18. https://doi.org/https://doi.org/10.24239/jsi.v12i1.377.1-18

Nia. (2011). Ini Dia 20 Lembaga Penerima Zakat yang "Diakui” Ditjen Pajak. 

and Supervision Program

Retrieved April 20, 2018, from https://finance.detik.com/berita-ekonomibisnis/d-1792590/ini-dia-20-lembaga-penerima-zakat-yang-diakui-ditjenpajak

Pambudhy, A. (2018). Pertumbuhan Ekonomi Indonesia Kuartal-I 2018. Retrieved April 20, 2018, from https://finance.detik.com/foto-bisnis/d3977063/pertumbuhan-ekonomi-indonesia-kuartal-i-2018/2\#detailfoto

Pless, N. M. (2012). Social Entrepreneurship in Theory and Practice-An Introduction. Journal of Business Ethics, 111(3), 317-320. https://doi.org/10.1007/s10551-012-1533-x

Rahmayati, A. (2015). Filantropi Islam: Model dan Akuntabilitas. In Menakar Masa Depan Profesi Menuju MEA 2015 Menuju Era Crypto Economic. Surakarta: Universitas Muhammadiyah Surakarta.

Schoenbachler, D. D., Gordon, G. L., Foley, D., Spellman, L., Schoenbachler, D. D., Gordon, G. L., ... Spellman, L. (1997). Understanding consumer database marketing. Journal of Consumer Marketing, 14(1), 5-19. https://doi.org/http://dx.doi.org/10.1108/07363769710155820

Setiawan, S. R. D. (2018). Ekonomi Indonesia 2017 Tumbuh 5,07 Persen, Tertinggi Sejak Tahun 2014. Retrieved April 20, 2018, from https://ekonomi.kompas.com/read/2018/02/05/113820026/ekonomiindonesia-2017-tumbuh-507-persen-tertinggi-sejak-tahun-2014

Tracey, P., \& Phillips, N. (2007). The distinctive challenge of educating social entrepreneurs: a postscript and rejoinder to the special issue on entrepreneurship education. Academy of Management Learning \& Education, $6(2), 264-271$.

Wahid, N. (2014). Keuangan Inklusif Membongkar Hegemoni Keuangan: Peran Kredit Usaha Rakyat dalam Menurunkan Kemiskinan dan Pengangguran. Jakarta: KPG (Kepustakaan Populer Gramedia) Bekerjasama dengan Inter Cafe IPB dan OJK.

Wibisono, Y. (2016). Potensi Zakat Nasional: Peluang dan Tantangan Pengelolaan. Depok.

Wolfe, D. B. (1997). Older markets and the new marketing paradigm. Journal of Consumer Marketing, 14(4), 294-302. https://doi.org/10.1108/07363769710188545 
Mansur Efendi

Halaman ini sengaja dikosongkan 